Original Paper

\title{
Penurunan Bahan Organik Sisa Aktifitas Budidaya Organisme Air
}

\author{
Diana Arfiati ${ }^{1}$, Sri Dayuti ${ }^{1}$, Setya Widi A.P. ${ }^{1}$, Nunik Cokrowati ${ }^{2}$ \\ ${ }^{1}$ Fakultas Perikanan dan Ilmu Kelautan, Universitas Brawijaya,Malang, Indonesia; \\ ${ }^{2}$ Program Studi Budidaya Perairan, Universitas Mataram, Mataram, Indonesia.
}

*Corresponding Author:

Nunik Cokrowati,

Universitas Mataram,

Mataram, Indonesia;

Email:

nunikcokrowati@unram.ac.id

\begin{abstract}
Daerah muara sebagian besar dimanfaatkan oleh masyarakat pesisir untuk kegiatan budidaya perikanan seperti tambak. Limbah yang dihasilkan oleh tambak langsung dibuang ke sungai tanpa diolah terlebih dahulu. Secara umum petambak tidak menyadari bahwa limbah yang terbuang itu menambah beban organik perairan, apalagi bahan organik tersebut tidak segera terurai menjadi bahan an organik. Pada daerah pesisir ditumbuhi beragam tanaman mangrove tetapi tanaman tersebut tidak dapat manfaatkan bahan organik bahkan bahan organik dapat menghambat pertumbuhannya. Di sisi lain mangrove merupakan ekosistem pesisir yang berguna untuk melindungi pantai, kerusakan mangrove akan berakibat bencana bagi daratan di belakangnya. Maka dari itu perlu adanya upaya untuk menginformasikan masyarakat menegnai cara menurunkan bahan organik dari limbah usaha budidaya agar perairan pesisir tidak tercemar dan tumbuhan dapat tumbuh dengan baik dan sehat sesuai fungsinya. Wilayah pesisir memerlukan perlindungan agar tidak terjadi abrasi atau pengikisan tepain pantai. jika terjadi pengikisan ini maka lama kelamaan pesisir pantai tersebut akan terkikis. Perlindungan pesisir bisa dilakukan dengan menanam mangrove maupun dengan menanam pohon pelindung pantai. maka dari itu, penyuluhan ini diperlukan agar masyarakat di sekitar pesisir pantai.
\end{abstract}

Keywords: Kerang Kijing; mangrove; tambak; limbah, muara.

\section{Pendahuluan}

Pencemaran merupakan penyebab utama terjadinya kerusakan ekologis mangrove, pada umumnya disebabkan oleh akumulasi limbah dari aktivitas manusia di wilayah pesisir maupun dari Daerah Aliran Sungai (DAS). Kawasan pesisir Indonesia dalam hubungannya dengan letaknya yang strategis, sifatnya yang rentan terhadap perubahan ditambah dengan kemudahan akses dan hubungan antar pulau dan antar wilayah maka diperlukan kelestariannya. Pengelolaan kawasan pesisir dapat dikatakan merupakan komponen penting yang perlu diperhatikan dalam menunjang pembangunan di Indonesia.

Kawasan pesisir tidak dapat dipisahkan dengan wilayah muara dan sungai yang bermuara ke wilayah tersebut. Sungai merupakan ekosistem air tawar alami yang berfungsi sebagai tempat hidup organisme perairan baik fauna dan flora. Sungai merupakan unsur penting dalam kehidupan

Publisher

UPT Mataram University Press makhluk hidup terutama manusia sebagai sumber air minum, irigasi, perikanandarat, ataupun rekreasi (Katili, 2011). Sungai mempunyai kemampuan untuk membersihkan diri (self purification) dari berbagai sumber masukan, akan tetapi jika melebihi kemampuan daya dukung sungai tersebut (carrying capacyty) maka akan menimbulkan masalah pencemaran sungai (Setiawan, 2009).

Sungai yang telah tercemar oleh buangan limbah pabrik, limbah rumah tangga ataupun limbah pertanian, peternakan dan perikanan akan mengakibatkan sungai tidak dapat berfungsi sebagaimana mestinya dan mempengaruhi kehidupan organisme perairan yang ada didalamnya (Palinussa, 2010). Beberapa kegiatan budidaya atau pertambakan berada di daerah pesisir dan beberapa kegiatan dipesisir tersebut berdampingan dengan hutan mangrove. Hasil buangan budidaya ini dirasa mengakibatkan bertambahnya bahan organik dalam perairan, karena tidak melalui pengolahan terlebih dahulu. 
Masalah lingkungan yang menjadi perhatian beberapa pihak, baik pembudidaya, industri yang membuang limbahnya ke sungai maupun masyarakat di sekitar sungai yang memasukkan sisa kegiatannya ke dalam sungai. Aktivitas perikanan budidaya akan membuang limbah budidayanya setelah akhir masa pemeliharaan dengan bahna organik yang ada dalam sisa budidaya tersebut yang dapat mencemari lingkungan perairan. Budidaya secara intensif mengakibatkan banyaknya limbah yang dihasilkan (Gunadi, 2012) terutama dari sisa pakan, sisa aktivitas metabolisme organisme budidaya seperti urine dan faeces. Pencemaran lingkungan yang diakibatkan oleh limbah budidaya perikanan dipicu oleh penggunaan pakan yang tidak terkontrol dan penggunaan obat yang kurang ramah lingkungan. Adanya peningkatan jumlah pakan yang diberikan pada budidaya dapat menimbulkan peningkatan bahan organik (Suwoyo, et al., 2015). Sebanyak 100 gram unit pakan yang diberikan pada umumnya $25 \%$ digunakan untuk pertumbuhan dan $25 \%$ untuk metabolismenya, sisanya tidak termakan dan menjadi limbah padat atau cair pada perairan (Setiawan et.al., 2016). Limbah budidaya ikan memiliki kadar bahan organik sekitar 33,7-46,8\% (Moccia et al., 2007), misalnya kandungan bahan organik pada kolam budidaya ikan lele menagndung 78,37-126,40 mg/l, nilai ini jauh diatas baku mutu yaitu 20-40 mg/l (Effendi, 2003).

Pantai Clungup merupakan pantai di kawasan Sendangbiru yang berlokasi di Desa Tambakrejo Kecamatan Sumbermanjing Wetan, Kabupaten Malang. Clungup Mangrove Conservation (CMC) merupakan kawasan pesisir yang memiliki ekosistem terlengkap di pesisir Kabupaten Malang. Pada kawasan CMC ini, kawasan mangrove memiliki luas area kurang lebih $81 \mathrm{Ha}$ dan kawasan Greenbelt seluas $117 \mathrm{Ha}$. Pantai Clungup termasuk pantai pasir yang berasosiasi dengan terumbu karang. Kawasan ini juga banyak dijumpai kegiatan budidaya pertambakan. Sehingga dengan berjalannya waktu maka kondisi lingkungan di muara sungai apabila tidak dijaga maka akan mempengaruhi keberhasilan konservasi mangrove.

\section{Metode}

Tujuan pelaksanaan kegiatan pengabdian kepada masyarakat ini adalah untuk memberikan pembelajaran kepada masyarakat tentang arti pentingnya ekosistem sungai yang bermuara di wilayah hutan mangrove, serta memberikan pembelajaran tentang pengelolaan air sisa dari kegiatan budidaya sekitar pesisir agar air yang dibuang tidak mencemari ekosistem lainnaya yang berada pada daerah muara sungai dan pesisir khususnya hutan mangrove.

Metode penyuluhan dilakukan dengan penyampaian materi secara langsung kepada masyarakat dalam bentuk ceramah. Materi penyuluhan yang diberikan adalah pentingnya konservasi sungai dalam mendukung program konservasi mangrove, karaketristik bahan pencemar, cara mengendalikan pencemaran organik dan cara mengurangi bahan pencemar organik dari sisa budidaya perikanan.

\section{Hasil dan Pembahasan}

Kegiatan pengabdian kepada masyarakat ini dilakukan pada acara "Cangkrukan Clungup Mangrove Center" yang diprakarsai oleh Universitas Brawijaya dan CMC (Clungup Mangrove Center) dengan mengundang beberapa pakar dari Fakultas Ilmu Komputer, Fakultas Teknik, Fakultas Matematika dan Ilmu alam dan Fakultas Perikanan dan Ilmu Kelautan Universitas Brawijaya, Dinas Kelautan dan Perikanan Kabupaten Malang serta beberapa LSM seperti Clungup Mangrove Center, Mitra Bahari, Jugo Dewaruci serta dihadiri oleh masyarakat sekitar.

Adapun strategi pengelolaan muara sungai untuk menanggulangi masalah tersebut didasarkan pada beberapa perrtimbangan seperti jenis pemanfaatan muara sungai, operasi dan pemeliharaan, dampak lingkungan dan sebagainya. Dua pilihan dasar yang perlu ditinjau adalah (Gunadi, 2012):

a. Muara sungai selalu terbuka. Supaya mulut sungai selalu terbuka diperlukan dua buah jeti panjang untuk menghindari sedimentasi di dalam alur maura dan pembentukann sand bar. Dalam menanggulangi erosi yang terjadi di hilir jeti, diperlukan bangunan pengendali erosi yang dapat berupa revetmen, groin, pemecah gelombang atau kombinasi dari ketiganya.

b. Muara sungai boleh tertutup. Ada dua pilihan yaitu mulut sungai tidak boleh berbelok atau boleh berpindah. Pembelokan muara sungai dapat menyebabkan sungai semakin panjang dan dapat mengurangi kemampuannya untuk 
melewatkan debit. Dalam menahan pembelokan muara sungai perlu dibuat jeti sedang, jeti pendek, bangunan di tebing mulut sungai, atau pengerukan rutin endapan.

Hampir sebagian besar daerah muara sungai dan pesisir digunakan oleh masyarakat setempat untuk kegiatan budidaya perikanan. Dengan adanya kemajuan teknologi budidaya perikanan pada satu sisi dapat meningkatkan produksi sektor perikanan, namun di sisi lain dengan padat tebar yang tinggi serta pemberian pakan yang berlebihan dapat menyebabkan pergeseran keseimbangan anatar lingkungan, ikan yang dipelihara dan patogen penyebab penyakit. Pergeseran keseimbangan ini menyebabkan stess pada ikan, sehingga mekanisme pertahanan diri yang dimilikinya menjadi lemah dan akhirnya terserang oleh penyakit.

Strategi penurunan bahan organik pada kegiatan budidaya dapat dilakukan dengan menggunakan filter secara biologi atau biofilter. Biofilter merupakan reaktor biologisfilm-tetap (fixed-film) menggunakan packing berupa kerikil, plastik, atau bahan padat lainnya dimana limbah cair dilewatkan melintasi secara kontinyu. Bivalve merupakan biota akuatik yang bisa digunakan sebagai biofilter dalam mengurangi kadar sisa bahan organik. Diantara jenis bivalve yang dapat digunakan sebagai biofilter (filter biologi) adalah kijing taiwan (Anadara woodiana). Kijing air tawar dapat memanfaatkan sisa pakan dan metabolisme ikan sehingga dapat dijadikan sebagai biofilter (Putra et.all, 2016). Kemampuan kijing taiwan dalam menyerap bahan organik dapat dimanfaatkan sebagai biofilter dalam melengkapi filter fisik yang digunakan dalam pengelolaan limbah budidaya ikan lele. Menurut Gunawan (2000) Kijing merupakan hewan filter feeder yang mampu memindahkan bahan organik seperti sedimen dan bahan organik dari kolom air.

Masyarakat sekitar antusias dalam menerima materi dari tim kegiatan mengenai cara menurunkan bahan organik pada perairan khususnya bahan organik yang terkandung dalam air sisa budidaya perikanan. Kenyataannya, banyak para petani tambak tidak mengolah limbahnya dan langsunbg dibuang di perairan. Sehingga dapat mencemari daerah sekitar muara yang selanjutnya akan mencemari wilayah pesisir. Sedangkan masyarakat sekitar sudah peduli dengan kelestraian ekosistem pesissir diantaranya adlaah kawasan mangrove. Dengan adanya penyuluhan yang kami berikan diharapkan mereka dapat menegur para petambak dengan memberikan solusi seperti yang telah tim kegiatan ini berikan.

\section{Kesimpulan}

Masyarakat mitra mendapatkan pembelajaran mengenai arti pentingnya ekosistem sungai yang bermuara di wilayah hutan mangrove, serta pembelajaran mengenai pengelolaan air sisa dari kegiatan budidaya sekitar pesisir agar air yang dibuang tidak mencemari ekosistem lainnya.

\section{Saran}

Kegiatan seperti ini hendaknya dilakukan rutin dengan tema lain sesuai kebutuhan masyarakat dan hendaknya dilakukan juga pada daerah pesisir lainnya.

\section{Ucapan Terimakasih}

Ucapan terimakasih disampaikan kepada seluruh pihak yang mendukung kegiatan ini dan masyarakat mitra kegiatan ini.

\section{Daftar Pustaka}

Effendi, H. 2003. Telaah kualitas air, bagi pengelolaan sumberdaya dan lingkungan perairan. Penerbit Kanisius. Yogyakarta.

Gunadi, B. 2012. Minimalisasi limbah nitrogen dalam budidaya ikan Lele (Clarias gariepinus) dengan sistem akuakultur berbasis jenjang rantai makanan. Disertasi. Fakultas Perikanan dan Ilmu Kelautan. Institut Pertanian Bogor. Bogor.

Gunawan, T. 2000. Rancangan sistem teknologi pengolahan limbah cair. Disertasi. Program Pasca Sarjana Ilmu Lingkungan. Universitas Sebelas Maret. Surakarta.

Katili, A. 2011. Struktur Komunitas Echinodermata Pada Zona Intertidal di Gorontalo. Jurnal Penelitian dan Pendidikan, 8(1): 51-61

Moccia, R., Bevan D., and Reid G. 2007. Compotition of fecal waste from commercial Trout farm in Ontario: Macro and micro nutrient analyses and recommendations for 
recycling. Aquaculture Centre Universityof Guelph.

Palinussa, E. 2010. Pemanfaatan kijing Taiwan (Anodonta woodina) sebagai biofilter pada sistem budidaya ikan Mas. Tesis. Sekolah Pasca Sarjana. Institut Pertanian Bogor. Bogor.

Putra, S., A. Arianto, E. Efendi, Q. Hasani dan H. Yulianto. 2016. Efektifitas kijing air tawar (Pilsbryoconcha exilis) sebagai biofilter dalam sistem resirkulasi terhadap laju penyerapan amoniak dan pertumbuhan ikan Lele Sangkuriang (Clarias gariepinus). $e$ Jurnal Rekayasa dan Teknologi Budidaya Perairan. 4 (2): 497-506.

Setiawan, D. 2009. Studi komunitas makrobenthos di perairan hilir sungai Lemantang sekitar daerah Pasar Bawah Kabupaten Lahat. Skripsi. Jurusan Biologi FMIPA. Universitas Sriwijaya. Sulawesi Selatan.

Suwoyo, H. S., Tahe, S., \& Fahrur, M. 2015. Karakteristik limbah sedimen tambak udang vaname (Litopenaeus vannamei) superintensif dengan kepadatan berbeda. Prosiding Forum Inovasi Teknologi Akuakultur 2015. Pusat Penelitian dan Pengembangan Perikanan Budidaya. Jakarta. hlm. 901-913. 